\title{
Estimating the Economic Efficiency of Sheep Rearers in Al-Hasakah Governorate/Syria Using the Data Envelopment Analysis
}

\author{
Mohannad Alobid* \\ Faculty of Economics and \\ Business, Institute of Applied \\ Economics Sciences, University of \\ Debrecen, H-4032 Debrecen,
} Hungary

\author{
Alaa Hammo \\ Department of Agricultural \\ Economic, Faculty of \\ Agriculture, University of \\ Damascus, Damascus, Syria
}

\author{
István Szücs \\ Faculty of Economics and \\ Business, Institute of Applied \\ Economic Sciences, University of \\ Debrecen, H-4032 Debrecen, \\ Hungary
}

*Corresponding author: Email address: mohannad.alobid@econ.unideb.hu

\begin{abstract}
The main objective of the research is to measure the economic efficiency of sheep rearers in Al-Hasakah Governorate using the data envelopment analysis method. The sample size was 313 rearers, who were selected by random sampling method from the administrative regions of Al-Hasaka Governorate. The primary data for the two seasons 2018/2019 and 2019/2020 were collected according to a questionnaire form prepared for this purpose. The findings revealed that the variable costs and the cost of feed accounted for $71.16 \%$ and $45.83 \%$ of the total production costs, respectively, additionally, the milk revenues ranked first as a main source of income with a rate of $61.90 \%$. The results, on the other hand, revealed that levels of technical efficiency in response to changes in return on capacity ranged from a minimum of $27 \%$ to a maximum of $100 \%$, with an average of $73.9 \%$, Furthermore, allocative efficiency levels ranged from a minimum of $93 \%$ to a maximum of $100 \%$, with an average of $98 \%$; while economic efficiency levels ranged from a minimum of $27 \%$ to a maximum of $100 \%$, with an average of $73.2 \%$.
\end{abstract}




\section{Introduction}

The administration process faces a wide range of challenges, all of which must be met in order to achieve the highest possible level of productivity, efficiency, and effectiveness in order to achieve their progress and prosperity goals. At the same time, administrative decisions must be rational and balanced, not based on intuition or trial and error, but rather based on a scientific basis whose main pillar is the scientific method. Additionally, the success of any institution is judged by its ability to reduce inputs and maximize outputs without sacrificing the essence of the production process since the system becomes efficient if its outputs are at the highest rate and at the lowest cost possible (Cylus, Papanicolas, \& Smith, 2017).

As a result, the necessity for or willingness to use advanced scientific approaches to justify decision-making in order to face the problems has grown. The measurement of technical efficiency presupposes that the limitations of the production function, which is defined by consistent efficiency in production processes, are known, and that the limits of the production function are unknown in practice because it calculates the distance from the efficient boundary curve that should be estimated from the sample data, it assesses the relative efficiency of production units (Constantin, Martin, Rivera, \& De, 2009).

The Data Envelopment Analysis (DEA) is one of these methodologies, which uses a non-parametric approach. This approach was characterized as a mathematical method that employs linear programming to measure the relative effectiveness of a number of administrative units by determining the best mix for its input group, which is based on an essay published by Leal Paço and Cepeda Pérez (2013). In order to construct its actual performance, it has to have a set of outputs and a set of inputs.

Because the DEA approach is based on linear programming, it identifies the regions that are most important to extension efforts. As a result of employing this analytical technique and its measurability and sources of inefficiency, there will be less effort to attain a goal. This method also provides detailed information related to the use of the inputs, the optimum mix of them, the efficiency of each farm and/or barn, its measurability, and the sources of inefficiency in it.

Sheep breeding occupies an important position in livestock production, and this is due to the economic advantages that are available when raising it, such as the low investment costs and labor costs needed to care for it, the low price of sheep and the speed of turnover of the invested capital (Jahnke \& Jahnke, 1982; Kamuanga, Somda, Sanon, \& Kagoné, 2008). Additionally, Sheep and goats have a great ability to graze and adapt to dry and desert environments (Joy, Dunshea, Leury, Clarke et al., 2020; Shankarnarayan, Bohra, \& Ghosh, 1985). Furthermore, sheep breeding is a way to use the waste that remains of agricultural crops after harvest (Dalibard, 1995), as well as, the diversity of their production as they give meat, milk, wool and leather, which are raw materials for many industries, that have constantly high prices of their products because of the increasing demand for them (FAO, 2013; Jarrell, 2011; Morris, 2017), especially on festive/ethnic holidays (Lawal-Adebowale, 2012). Moreover, sheep breeding produces an organic fertilizer that has a high fertilizing value (Lal, Sharma, Meena, Sarkar et al., 2020).

Sheep breeding is one of the main sources of income for a large segment of farmers in the AlHasakah Governorate, where the number of sheep in Syria reached around 14 million heads in 2018, with 10\% of those in the Al-Hasakah Governorate (W. FAO, 2019; MOAAR, 2021).

When the VRS output-oriented DEA model was applied to sheep rearers in Greece, Theodoridis, Ragkos, Roustemis, Galanopoulos et al. (2012) found that $31.03 \%$ of the surveyed rearers had 100 $\%$ full technology efficiency, $18.97 \%$ of the rearers had technical efficiency ranged between $0.80 .8-99 \%, 24.14 \%$ of rearers had technical efficiency between $(0.6-0.79) \%$, and $25.9 \%$ of rearers had technical efficiency less than 60\%. In addition, Theodoridis et al. (2012) found the average technical efficiency was about 0.76 , which indicates the possibility of an increase of $24 \%$ from the value of Production using the level of inputs and technology. Whereas Bojnec, Latruffe, and University of Primorska - Faculty of Management Koper (2007) when applying the VRS outputoriented DEA model to sheep rearers in Slovenia found that the technical efficiency was 1, and the allocative and economic efficiency was 0.621.

The problem of the study and its importance is the inability of local production to meet the increasing consumer needs, due to the decline in the number of live sheep from 1.6 million heads in 2011 to 1.4 million heads in 2018 , with a decrease rate of about $12.5 \%$, this decline is attributed to the suffering of the livestock sector in Al-Hasakah Governorate, due to multiple reasons: the 
most important of which are the economic challenges, given the high prices of production factors (requirements), as well as price fluctuations and instability from one period to another, in addition, some rearers economizing on their use, which led to their deviation from the achieved levels of economic efficiency, which is a tool to identify weaknesses and defects in the management of the livestock sector and the policies followed in this field, additionally, the extent to which the economic efficiency of the production factors used is achieved, which makes it a basis for the rearers to rely on when making his production decisions to add or reduce a worker in a way that achieves his desired goals.

Accordingly, the research aimed to conduct an economic analysis of both costs and revenues and to measure economic efficiency and its technical and allocative components using the data envelopment analysis method for sheep rearers in the study area.

In this context, the main objective of this study is to measure the economic efficiency of sheep rearers in Al-Hasakah Governorate using the data envelopment analysis method. The remainder of the article is structured as follows: The next section presents a material and method which is including the study regions, economical methods and description of the model used to estimate the economic efficiency and its components by using the Data Envelopment Analysis (DEA) method. Result and discussions of the study are discussed in the third section. Finally, concluding remarks and recommendation of the research are presented in last section.

\section{Material And Method}

The research was carried out for the selected sample of sheep rearers in the villages of the administrative regions (Al-Hasakah Center - Qamishli - Al-Malikiyah - Ras Al-Ain) in Al-Hasakah Governorate for an average of the two seasons 2018/2019 and 2019/2020. The number of villages reached about 726 from which 194 villages were in the center of Al-Hasakah, 156 villages in the Malikiyah region, 180 villages in the Ras al-Ain region, and 196 villages in the Qamishli region. The villages were randomly selected by $5 \%$ of the number of specified villages, thus bringing the total number of villages covered by the questionnaire to 35 villages. Based on a simple random sampling method, the number of sheep rearers was gathered from the agricultural extension centers to which the villages belong. The overall number of sheep rearers in the surveyed villages was estimated to be around 1689, with a sample size of 313 rearers at a $5 \%$ level of significance according to (Krejcie \& Morgan, 1970), as following equation:

Where:

$$
S=\frac{X^{2} N P(1-P)}{D^{2}(N-1)+X^{2} P(1-P)}
$$

S: Sample size ;

$X^{2}$ : A constant value of the degree of freedom at the desired level and is estimated (3.841);

$\mathrm{N}$ : population size;

$\mathrm{P}$ : The population ratio is a constant value of (0.5);

$D$ : The degree of accuracy is a constant value which is estimated at (0.05).

The following numbers is how the sample was allocated based on the percentage of rearers in each administrative region: Al-Hasakah has around 107 rearers, Al-Malikiyah has about 54, Ras AlAin has about 63, and Qamishli has about 89. The primary data was collected via personal interviews with sheep rearers through a field survey in the study area, according to a questionnaire form prepared for this purpose. Two programs were used to conduct the analysis (Excel and Deap$\mathrm{xp} 1)$.

\section{Economical methods}

The economic analysis was carried out based on the following set of economic indicators:

Total production costs : Calculated based on (Belloin, 1988; C Raineri, 2012; Camila Raineri, Stivari, \& Gameiro, 2015) and it includes the following:

\subsubsection{Fixed costs (Syrian Pound (SP) / Head / Year) which are as follows:}

i. Head Depreciation (SP / Head / Year) = The value of the head at the time of purchase $\div$ The head's economic life (the age during which the head continues to produce until the value of production equals the value of costs). 
ii. Sheepfold Depreciation (SP / Head / Year) $=$ (the area of the sheepfold per head $x$ the value of the square meter) $\div$ the economic life of the sheepfold.

iii. Warehouse Depreciation (SP / Head / Year) $=$ (warehouse area per head $\times$ the value of the square meter) $\div$ the economic lifespan of the warehouse.

iv. The deaths and emergency slaughter: This cost is calculated at $1 \%$ of the head value.

$v$. Capital of interest: It is determined using the real interest paid by the rearer when the loan is obtained, as well as other production needs.

2.1.1.2 Variable costs (SP / Head / Year): It covered the cost of all types of feed, energy, water, and power, as well as veterinarian bills, veterinary drugs, and immunizations, repair costs, wages for shepherds and laborers and a petty cash costs (C Raineri, 2012; Camila Raineri et al., 2015).

Total Revenue (SP / Head / Year): It included the value of milk sales (the main revenue), the value of the newborn, and the value of the meat (secondary revenue).

2. 1.2.1 The value of milk (SP / Head / Year): Calculated by estimating the amount of milk produced for each head of milk (the quantity of milk kg/day $\times$ the length of milking season/day) $\times$ selling price per kilogram (Belloin, 1988).

2.1.2.2 The value of the newborn (SP / Head / Year): The value of the newborn was calculated by estimating the selling price in Syrian pounds and subtracting $10 \%$ of the price for the death rate (Belloin, 1988).

2. 1.2.3 The value of the overlooked meat (SP / Head / Year): The value of the milking head that was excluded from the herd was estimated at half its price divided by its economic life, meaning that the value of the overlooked meat $=$ a head for half the price SP $\div$ the economic lifespan per head (Belloin, 1988).

\section{Description of the model used to estimate the economic efficiency and its components by using the Data Envelopment Analysis (DEA) method}

\section{The Technical Efficiency (TE)}

Technical efficiency was estimated on the input side because its use and cost could be reduced more than ensuring increased production, With the presence of the independent variables represented by (K) mentioned in Table (1), In addition to knowing the input prices used Pxl to measure economic efficiency, this can affect the dependent factor $M$ given in Table (2), which was represented by the production value of the sample rearers $(N)$. Via using Duality in linear programming, the DEA model used in terms of inputs and by assuming the VRS as the following equation (Coelli, 1996):

$\operatorname{Min} \lambda, x_{i}^{*} W_{i}^{\prime} X_{i}^{*}$,

Subject to: $-y_{i}+Y \lambda \geq 0$,

$\theta x .^{*}-X \lambda \geq 0$,

$\mathrm{i}=1,2, \ldots \ldots . . \mathrm{N}$

$N_{i}{ }^{\prime} \lambda=1$

$\lambda \geq 0$

Where:

$x_{i}$ : the input value, $y_{i}$ : the output value, $X$ : the input matrix $N^{*} k, Y$ : the output matrix $1^{*} M$.

$\mathrm{X}_{.}{ }^{*}$ : the vector quantities of farm inputs used, $\lambda$ : the vector $N^{*}$ l represents a Standard weights, $w_{i}$ : Input prices used, $\theta$ : vector technical efficiency index of rearers $\mathrm{i}$.

\section{The total economic efficiency (EE):}

The following formula (2) was used to compute the economic efficiency, which was determined by the ratio of the minimum cost to the actual cost (Coelli, 1996).

$E E_{i}=w_{i}{ }^{\prime} x_{i}^{*} / w_{i}{ }^{\prime} X_{i}$

\section{The Allocative Efficiency (AE)}

After calculating the economic efficiency, the allocative efficiency was calculated from the following equation (3) (Coelli, 1996):

$A E_{i}=E E_{i} / T E_{i}$ 


\section{Result and Discussions}

\section{Total production costs and their relative importance}

Table 1 shows that variable costs and feed costs accounted for $71.16 \%$ and $45.83 \%$ of the total production costs, respectively, where sheep's nutrition depends primarily in the winter on fodder concentrates (barley), and filler fodder (hay), which they obtain either from their fields or by purchasing them, In addition to the constant grazing daily. As can also be shown in table 1, fixed costs accounted for an average of 28.84 percent of overall production costs, with sheep depreciation accounting for 62.52 percent of the fixed costs.

Table 1

Total production costs, and their relative importance in the study area

\begin{tabular}{cccc}
\hline & The Attribute & The Value (SP / Head / Year) & $\%$ \\
\hline \multirow{4}{*}{ Sixed costs } & Sheepfold and Warehouse Depreciation & 557.5 & 1.47 \\
& Head Depreciation & 6835.6 & 18.03 \\
& The deaths and emergency slaughter & 1098.85 & 2.90 \\
& Capital of interest & 2441.04 & 6.44 \\
\hline Total fixed costs & 10932.99 & 28.84 \\
\hline \multicolumn{2}{c}{ Feeds value } & 17375 & 45.83 \\
Energy, water, and power & 1223.63 & 3.23 \\
Variable costs & veterinarian bills, veterinary drugs, and & 2296.57 & 6.06 \\
& immunizations & 4800 & 12.66 \\
& Wages for shepherds and laborers & 1284.76 & 3.39 \\
& Petty cash cost & 26979.96 & 71.16 \\
\hline Total variable costs & 37912.95 & 100 \\
\hline Total production costs & &
\end{tabular}

Source: calculated by the authors

\section{Total revenue and its relative importance}

Table (2) shows that the study sample's rearers earned an average of 65 thousand SP/head/year, with revenue from sold milk ranking first at $61.90 \%$, followed by revenue from selling newborns at $32.72 \%$, and organic fertilizer having no value because most rearers use their animals' manure for their fields or throw it away, so it is not included in the economic calculation.

Table 2

The total revenue, and its relative importance in the study area

\begin{tabular}{lcc}
\multicolumn{1}{c}{ The Attribute } & The Value (SP / Head / Year) & $\%$ \\
\hline Milk revenue & 40420 & 61.90 \\
Newborn revenue & 21368.07 & 32.72 \\
Wool revenue & 91.28 & 0.14 \\
Overlooked meat revenue & 3417.8 & 5.23 \\
Total revenue & 65297.15 & 100 \\
\hline
\end{tabular}

Source: calculated by the authors

\section{Estimating the economic efficiency and its technical and allocative components}

The EE and its components, both TE and $\mathrm{AE}$, for sheep rearers in the study area, were estimated using the data envelopment analysis method and according to the variable costs mentioned in Table (1), in light of the quantities of factors used and their prices, assuming a change in volume returns as shown in the table (3).

Table 3

Results of estimating the technical, allocative and economic efficiency of sheep rearers using the DEA method.

\begin{tabular}{lccc}
\hline \multirow{2}{*}{ The Attribute } & \multicolumn{3}{c}{ The efficiency } \\
\cline { 2 - 4 } & TE \% & AE\% & EE\% \\
\hline Minimum & 0.277 & 0.931 & 0.277 \\
Maximum & 1 & 1 & 1 \\
Average & 0.742 & 0.989 & 0.735 \\
\hline
\end{tabular}

Source: calculated by the authors 
Table (3) shows that the levels of TE in light of the change in the return on capacity ranged between a minimum of $27 \%$ and a maximum of $100 \%$, with an average of $73.9 \%$, meaning that rearers seek to increase their production by $26.1 \%$, without any increase in the quantity or amount of the economic factors used, and the low TE, in general, can be attributed to the lack of optimal use of production factors due to their high prices, in addition to the small size of animal holdings, reliance on traditional methods, and the inability to benefit from the advantages of modern methods of production.

As for the AE levels of sheep rearers in the study sample, which was estimated considering the prices of the factors used, it is clear from Table (3) that the levels of allocative efficiency ranged between a minimum of $93 \%$, a maximum of $100 \%$ and an average of $98 \%$. The latter means that the redistribution of the economic factors used in sheep production will save $2 \%$ of the total production costs, and the high levels of AE can be attributed to the interest of the study sample rearers in the price relations of the economic factors used and production, due to their high prices, which led to the saving in their use. As shown in Table (3) the high levels of AE compared to the levels of TE, due to the interest of the study sample rearers in the price relations between the used production factors and their prices at the expense of the quantities used of them without the optimal quantities, as this use resulted in lower production costs, which led to higher AE.

Finally, the results in Table (3) showed that the levels of economic efficiency ranged from a minimum of $27 \%$ to a maximum of $100 \%$, with an average of $73.2 \%$, owing to the direct reflection of the results of the levels of technical efficiency. This result demonstrates that the study sample's rearers can maintain the same level of production while lowering production costs or reducing the number of factors required by $26.8 \%$. The study sample rearers inability to reach economic efficiency may be linked to the current conditions in the study area, as well as the resulting rise in the prices of production requirements, hence, their inability to choose the optimal resource combination.

\section{The Economic Efficiency Levels}

The results of the analysis in Table (4) showed that the number of rearers who achieved TE between (90.1-100\%) amounted to 40 rearers, and they constituted $12.9 \%$, while the number of rearers who achieved TE reached between (80.1 - 90\%) 91 rearers established of the rate of $29.3 \%$, as is the case for the number of rearers who achieved TE between (20-30) \%, and only one rearer made up $0.3 \%$.

Table 4

The levels of technical, allocative and economic efficiency, and the number of rearers and their percentage of the total sample of the study

\begin{tabular}{ccccccc}
\hline \multirow{2}{*}{ The efficiency level } & \multicolumn{2}{c}{ TE \% } & \multicolumn{2}{c}{ AE\% } & \multicolumn{2}{c}{ EE\% } \\
\cline { 2 - 7 } & $\begin{array}{c}\text { The Rearers } \\
\text { number }\end{array}$ & $\%$ & $\begin{array}{c}\text { The Rearers } \\
\text { number }\end{array}$ & $\%$ & $\begin{array}{c}\text { The Rearers } \\
\text { number }\end{array}$ & $\%$ \\
\hline $20-30 \%$ & 1 & 0.30 & - & - & 2 & 0.60 \\
$30.1-40 \%$ & 4 & 1.3 & - & - & 4 & 1.3 \\
$40.1-50 \%$ & 22 & 7.1 & - & - & 26 & 8.3 \\
$50.1-60 \%$ & 38 & 12.2 & - & - & 39 & 12.5 \\
$60.1-70 \%$ & 59 & 19.0 & - & - & 59 & 18.8 \\
$70.1-80 \%$ & 56 & 18.0 & - & - & 59 & 18.8 \\
$80.1-90 \%$ & 91 & 29.3 & - & - & 84 & 26.8 \\
$90.1-100 \%$ & 40 & 12.9 & 313 & 100 & 40 & 12.8 \\
Total & 313 & 100 & 313 & 100 & 313 & 100 \\
\hline
\end{tabular}

Source: calculated by the authors

Additionally, Table (4) shows that the number of rearers who achieved allocative efficiency between (90.1 - 100\%) 100\% amounted to 313 rearers and constituted 100\% of the total sample of the study, and this indicates that the rearers paid special attention to the prices of the economic factors used and the price relations between them.

While the levels of technical efficiency were reflected on the levels of economic efficiency, as the results of the analysis contained in the Table (4) showed that the number of rearers who achieved economic efficiency between (90.1-100\%) amounted to 40 rearers, and they constituted $12.8 \%$, 
while the number of educators that achieved efficiency reached technically, between (80.1-90\%) 84 rearers constituted of a rate of $26.8 \%$, as is the case for the number of rearers who achieved technical efficiency between (20-30)\%, and only one breeder made up $0.6 \%$.

\section{The Limitation of the Study}

- Data collection is difficult, especially in rural areas remote from cities.

- There had been instances where rearers have refused to participate in answering queries concerning financial problems.

- Some rearers give incorrect responses, which is sometimes owing to their lack of education.

\section{Conclusion and Recommendation}

- The price levels of the factors of production are the basis for their use, regardless of the optimal quantities of these factors.

- Rearers can increase their production by $26.1 \%$, without any increase in the amount and/or the number of economic factors used.

- Redistribution of the economic factors used in sheep production will save $2 \%$ of the total production costs.

- Higher levels of allocative efficiency competence compared to levels of technical efficiency.

- The reflection of the results of the levels of technical efficiency on the economic efficiency, that is, the sample rearers can achieve the same level of production in light of reducing production costs or reducing the number of factors used by $26.8 \%$.

- The study suggests focusing on increasing investment in the utilization of production factors in order to boost production to the optimal level.

\section{Acknowledgements}

This publication was supported by the construction EFOP-3.6.3-VEKOP-16-2017-00007 ("Young researchers from talented students-Supporting scientific career in research activities in higher education"). The project was supported by the European Union, co-financed by the European Social Fund.

\section{References}

Belloin, J.-C. (1988). Milk and dairy products: production and processing costs: FAO. Retrieved from https://www.fao.org/3/x6931e/x6931E00.htm

Bojnec, S., Latruffe, L., \& University of Primorska - Faculty of Management Koper, P., . (2007, 200711-20). Technical, scale, allocative and economic efficiencies in the Slovenian farms. Paper presented at the MIC'07 - Management International Conference 2007 : Managing global transitions: globalisation, localisation, regionalisation8. International conference of the Faculty of management Koper, Portorož (slovenia). Retrieved from https://hal.archives-ouvertes.fr/hal-02285617

Coelli, T. (1996). A guide to DEAP version 2.1: a data envelopment analysis (computer) program. Centre for Efficiency and Productivity Analysis, University of New England, Australia, 96 (08),

1-49. Retrieved from http://www.owlnet.rice.edu/ econ380/DEAP.PDF

Constantin, P. D., Martin, D. L., Rivera, R. Y., \& De, E. B. B. (2009). Cobb-Douglas, translog stochastic production function and data envelopment analysis in total factor productivity in Brazilian agribusiness. Journal of Operations and Supply Chain Management (JOSCM), 2 (2), 20-33. Retrieved from https://ageconsearch.umn.edu/record/289333/files/1 1846.pdf

Cylus, J., Papanicolas, I., \& Smith, P. C. (2017). How to make sense of health system efficiency comparisons? : World Health Organization, Regional Office for Europe Copenhagen. Retrieved from https://apps.who.int/iris/rest/bitstreams/1277157/retrieve

Dalibard, C. (1995). Livestock's contribution to the protection of the environment. World Animal Review, 104-112. Retrieved from https://www.fao.org/ag/Aga/agap/FRG/FEEDback/War/V8180b/v8180b 14.htm

FAO. (2013). In Vivo Conservation of Animal Genetic Resources (FAO Animal Production and 
Health Guidelines No. 14): FAO Rome. Retrieved from https://www.fao.org/3/i3327e/i3327e.pdf

FAO, W. (2019). Special Report: FAO/WFP Crop and Food Security Assessment Mission to the Syrian Arab Republic. Rome, Italy: FAO. Retrieved from https://www.fao.org/documents/card/en/c/ca5934en/

Jahnke, H. E., \& Jahnke, H. E. (1982). Livestock production systems and livestock development in tropical Africa (Vol. 35): Kieler Wissenschaftsverlag Vauk Kiel. Retrieved from https://pdf.usaid.gov/Pdf_Docs/PNAAN484.Pdf

Jarrell, T. T. (2011). The cultural history and future of sheep farming in the high country. MA Thesis. Appalachian State University, 2011. Print, Retrieved from https://libres.uncg.edu/ir/asu/f/Jarrell,\%20Tracy 2011 Thesis.pdf

Joy, A., Dunshea, F. R., Leury, B. J., Clarke, I. J., DiGiacomo, K., \& Chauhan, S. S. (2020). Resilience of small ruminants to climate change and increased environmental temperature: a review. Animals, 10(5), 867. Doi:https://doi.org/10.3390/ani10050867

Kamuanga, M. J., Somda, J., Sanon, Y., \& Kagoné, H. (2008). Livestock and regional market in the Sahel and West Africa: Potentials and Challenges: ECOWAS - SWAC/OECD. Retrieved from https://www.oecd.org/swac/publications/41848366.pdf

Krejcie, R. V., \& Morgan, D. W. (1970). Determining sample size for research activities. Educational and psychological measurement, 30(3), 607-610. Doi:https://doi.org/10.1177\%2F001316447003000308

Lal, B., Sharma, S., Meena, R., Sarkar, S., Sahoo, A., Balai, R. C., . . Meena, B. (2020). Utilization of byproducts of sheep farming as organic fertilizer for improving soil health and productivity of barley forage. Journal of Environmental Management, 269, 110765. Doi:https://doi.org/10.1016/i.jenvman.2020.110765

Lawal-Adebowale, O. (2012). Dynamics of Ruminant Livestock Management in the Context of the Nigerian Agricultural System. In Livestock Production: IntechOpen. Doi:https://doi.org/10.5772/52923

Leal Paço, C., \& Cepeda Pérez, J. M. (2013). The use of DEA (Data Envelopment Analysis) methodology to evaluate the impact of ICT on productivity in the hotel sector. Via. Tourism Review(3), 1-13. Doi:https://doi.org/10.4000/viatourism.1005

MOAAR. (2021). Statistical group for the year 2019. Retrieved from http://moaar.gov.sy/main/archives/23338

Morris, S. T. (2017). Overview of sheep production systems. In Advances in sheep welfare (pp. 1935): Elsevier. Doi:https://doi.org/10.1016/B978-0-08-100718-1.00002-9

Raineri, C. (2012). Development of a cost calculation model and cost index for sheep production in Sao Paulo state, Brazil. Development of a cost calculation model and cost index for sheep production in Sao Paulo state, Brazil.

Raineri, C., Stivari, T. S. S., \& Gameiro, A. H. (2015). Development of a cost calculation model and cost index for sheep production. Revista Brasileira de Zootecnia, 44, 443-455. Doi:https://doi.org/10.1590/S1806-92902015001200005

Shankarnarayan, K., Bohra, H., \& Ghosh, P. (1985). The goat: an appropriate animal for arid and semi-arid regions. Economic and Political Weekly, 20(45/47 Special Number), 1965-1972. Retrieved from https://www.jstor.org/stable/4375018

Theodoridis, A., Ragkos, A., Roustemis, D., Galanopoulos, K., Abas, Z., \& Sinapis, E. (2012). Assessing technical efficiency of Chios sheep farms with data envelopment analysis. Small Ruminant Research, 107(2-3), 85-91. Doi:https://doi.org/10.1016/j.smallrumres.2012.05.011 